\title{
Nitrogen and phosphorus removal and physiological response in aquatic plants under aeration conditions
}

\author{
${ }^{1 * X . M . ~ L u ;}{ }^{2}$ M. S. Huang \\ ${ }^{1}$ Institute for Eco-environmental Sciences, Wenzhou Vocational College of Science and Technology, \\ Zhejiang, China \\ ${ }^{2}$ School of Resources and Environment Sciences, East China Normal University, Shanghai, China \\ Received 26 January 2010; revised 12 July 2010; accepted 21 June 2010; available online 1 September 2010
}

\begin{abstract}
To analyze the variation of physiological responses between Nymphaea tetragona Georgi. and Pontederia cordata L. and the water qualities under aeration conditions, the selected plants were cultivated in 12 purifying-tanks (aeration, non aeration), to treat heavily polluted river water. The characteristics of both plants were investigated, which included contents of chlorophyll and soluble protein, activities of peroxidase and catalase, accumulations of nitrogen and phosphorus, densities of tillers and roots, lengths of roots, culms and leaves, biomass of roots and shoots. The water qualities were analyzed correspondingly. Results indicated that aeration affected morphological and physiological characteristics of the plants and the water qualities and effects became more significant on $N$. tetragona than P. cordata. Biomass and length of roots, culms and leaves under the non aeration conditions exceeded that under the aeration conditions. Aeration contributed to the activities increase of peroxidase and catalase of the roots and the contents decrease of chlorophyll and soluble protein of the leaves. Nitrogen and phosphorus contents of the roots, culms and leaves increased under the non aeration conditions. Aeration resulted in tillers and roots densities of $N$. tetragona decreased, while they increased for $P$. cordata. Total phosphorus and soluble phosphorus removals decreased $8.42 \%$ and $8.05 \%$ in the tank with $N$. tetragona under the aeration conditions. In the tank with $P$. cordata, total nitrogen and $\mathrm{NH}_{4}{ }^{+}-\mathrm{N}$ removals increased $14.44 \%$ and $16.06 \%$ under the aeration conditions. This work provided valuable data for optimizing the plants allocation in the ecological restoration project of the polluted water.
\end{abstract}

Keywords: Morphological and physiological characteristic; Nymphaea tetragona Georgi.; Pontederia cordata L.

\section{INTRODUCTION}

Increasing of industry and urban population leads to most urban rivers throughout China have been heavily polluted, especially the urban stagnant flow channels.

Dissolved oxygen concentrations of the stagnant flow channels almost turn to zero and there live few aquatic animals and plants direct to the poor selfpurification of the channels. Most of all, the typical reason of this phenomenon is lack of dissolved oxygen. Dissolved oxygen concentration directly affected the decomposition and degradation of the organic materials of the wastewater, even the selfpurification of the water (Bodelier et al.,1996; Kowalchuk et al.,1998; Kirk and Kronzucker, 2005). Therefore, the degradation of pollutants in stagnant water can be considerably improved by recovering dissolved oxygen. Artificial aeration was just an

× *Corresponding Author Email: xm155@sina.com Tel.: +86577 8885 5776; Fax: +86577 88423975 essential approach for the dissolved oxygen recover of the heavily polluted stagnant water and even the ecological restoration of the polluted stagnant flow channels. Numerous studies have recently been reported (Scholz and Lee, 2005; Ouellet-Plamondon et al. 2006; Akpor et al., 2008; Banu et al., 2008). Aeration technique meant that atmosphere or pure $\mathrm{O}_{2}$ was artificially pumped into polluted water and the dissolved oxygen was reinforced to increase and recover and the activities of the aerobic microbes in the water were returned and even enhanced. Thus, the organic materials were purified and the water quality was improved (Subhasis et al., 1999; Soltanali and Haghani, 2008; Madukasi et al., 2010). Engineering practices also demonstrated that aeration technique was effective to help treating polluted water (Scholz and Lee, 2005; Ouellet-Plamondon et al. 2006; Guo et al., 2008; Thakre et al., 2009; Igbinosa and Okoh, 2009).

Floating-beds form natural phytodepuration 
systems and artificially constructed floating-beds are currently used extensively for the purposes of treating domestic, agricultural and industrial effluent (Davies et al. 2005; Kovacic et al. 2006; Nahlik and Mitsch, 2006; Dhote and Dixit, 2009). An important part of the purification process is the oxidation of ammonium compounds to nitrite and nitrate (Kirk and Kronzucker, 2005); for this reason, the efflux of oxygen from the plant's roots promotes the growth of aerobic nitrifying bacteria (Bodelier et al.1996; Kowalchuk et al.1998). Therefore, aeration is suitable to enhance nitrogen removals. The plant-periphyton complex also plays an important biofilter role in the adsorption and retention of cations (Judith and Peddrick, 2004).

However, practical experiences demonstrated that when polluted stagnant water was aerated, except for the water quality improvement (Scholz and Lee, 2005; Ouellet-Plamondon et al., 2006), pressurized (convective) gas flow from the aerator affected the morphological and physiological characteristics of the aquatic plants under the certain conditions (such as, too high of the gas flow rate and too long of the aeration time), for the pressurized (convective) gas flow from the aerator most likely affected the exposed roots of the aquatic plants, especially the tender ones. Most of the literature studies on aquatic plant treatment of wastewater report purification efficiencies, but not the correlation between the purification and the physiological response of the aquatic plant. There are no reports about the effects of aeration on the morphological and physiological characteristics of the aquatic plants till now. However, knowledge about that aspect is of most importance to effectively utilize the combined technique of aquatic plants and artificial aeration to treat and restore the heavily polluted stagnant channels.

Physiological status of the aquatic plant was essential for the nitrogen and phosphorus absorption and removal of polluted water (Li et al., 2007). Enzymes activities of the plant tissues were associated with the physiological status of the plants. Adversity leaded to the superoxide radicals increased in the plant cells and caused the oxidation stress (Jabs, 1999; ElDiwani et al., 2009). There was an antioxidant enzyme system in the cells of the plant. Catalase and peroxidase were major components of the system and they had a synergy effect in scavenging and preventing active oxygen radicals (Kaufmann et al., 2002). Especially, peroxidase existed extensively in the cells, taking part in physiological activities and sensitive to adverse conditions (Tan et al., 2006). Hence, peroxidase was significantly associated with the plants resistance to adverse conditions (Li et al., 2000; Yousaf and Sarwar, 2008).

Both Pontederia cordata and Nymphaea tetragona have ornamental value, along with good purification ability, but are not extensively used in the environmental engineering till now. In this study, $P$. cordata (Fig. 1) and N. tetragona (Fig. 2) were employed to treat heavily polluted stagnant water from Gong-ye channel by field test. Effects of aeration on the morphological and physiological characteristics including peroxidase and catalase activities of the roots, chlorophyll and soluble protein contents of the leaves of the plants and the nitrogen and phosphorus removals of polluted water were analyzed.

The objective of this study is to investigate effects of artificial aeration on the physiological responses of

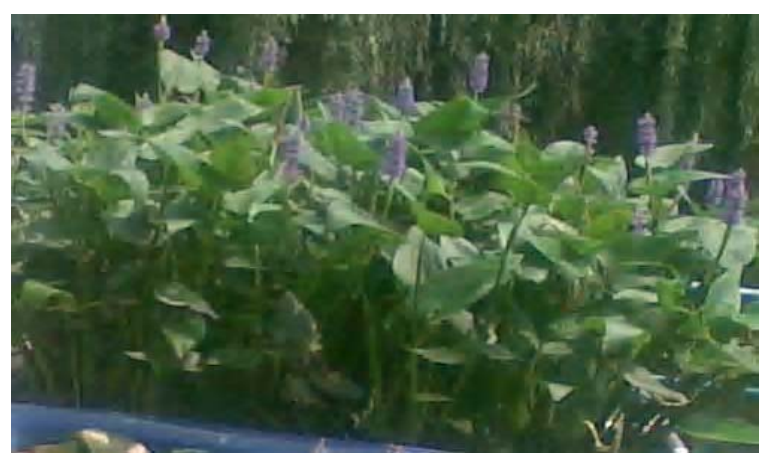

Fig.1: $P$. cordata under non aeration conditions on July $19^{\text {th. }}$ 2008

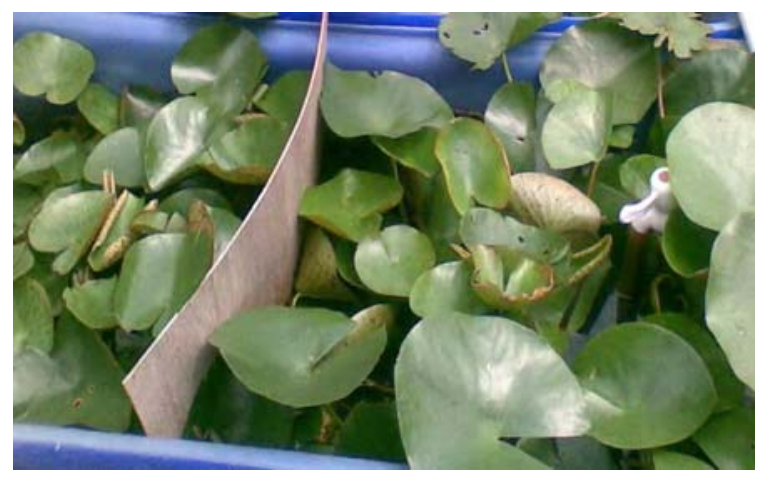

Fig. 2: N. tetragona under under non aeration conditions on July $19^{\text {th. }} 2008$ 
the aquatic plants and the variation of the water qualities to provide valuable data for employing aquatic plants to treat polluted stagnant water. Date and location of the research carried out throughout the study was On October $11^{\text {st. }} 2008$ and Gong-ye channel, respectively.

\section{MATERIALS AND METHODS}

Device construction and plant culture

Gong-ye channel is heavily polluted and stagnant. It lies in Pu-tuo district of Tao-pu town, Shanghai City. October $11^{\text {st }} 2008$, the quality of the polluted channel water was as follows: $\rho\left(\mathrm{COD}_{\mathrm{cr}}\right)$, $170.6-187.5 \mathrm{mg} / \mathrm{L} ; \rho\left(\mathrm{BOD}_{5}\right), 63.02-69.23 \mathrm{mg} / \mathrm{L} ; \rho$ $\left(\mathrm{NH}_{4}^{+}-\mathrm{N}\right), 30.81-34.17 \mathrm{mg} / \mathrm{L} ; \rho$ (total nitrogen), 51.35$53.39 \mathrm{mg} / \mathrm{L} ; \rho$ (soluble phosphorus), $0.144-0.146 \mathrm{mg} /$ $\mathrm{L} ; \rho$ (total phosphorus), 0.228-0.240 mg/L; $\mathrm{pH}, 7.9-$ 8.5 .

A test apparatus consisting of 14 purifying-tanks and one balance water tank were used as the experimental system. The device (Fig. 3) was composed of one balance water tank (upper dimension, L $1500 \mathrm{~mm} \times \mathrm{B} 1000 \mathrm{~mm}$; downside dimension, L $1450 \mathrm{~mm} \times$ B $950 \mathrm{~mm}$; High, $600 \mathrm{~mm}$ ) and 14 plastic purifying-tanksÿupper dimension, $\mathrm{L}$ $1240 \mathrm{~mm} \times$ B $620 \mathrm{~mm}$; downside dimension, L 1150 $\mathrm{mm} \times$ B $550 \mathrm{~mm}$; High, $760 \mathrm{~mm}$. The balance water tank had an overflow tube, to balance the water level and made every one of 14 tanks receive same influent. The polluted water was pumped into the balance water tank from the polluted river directly, through the fixed effluent tube into the purifyingtanks. The effluent tube on the purifying-tank monitored the water level in the tank at $0.60 \mathrm{~m}$ high. Each purifying-tank was separated by a baffle through the center and left about $20 \mathrm{~cm}$ space to the tank bottom to avoid causing water circuit flow. Each tank had a sediment exit on the bottom to discharge sediment mud every day. Continuous water flow was kept in each tank. Hydraulic retention time was $8 \mathrm{~h}$. The type of ACO-004 electromagnetic atmosphere pump (60 L/min) from Zhejiang Sensen Shiye Limited Company was employed to aerate six tanks continuously from February 2008 to October 2008. Gas flow rate in each of six tanks was $30 \mathrm{~L} / \mathrm{min}$. Seedlings of $P$. cordata (high $10 \mathrm{~cm}$ ) and $N$. tetragona (high $10 \mathrm{~cm}$ ) were collected from Shanghai Zelong Biology Engineering Limited Company. The seedlings were water cultured in purifying-tanks

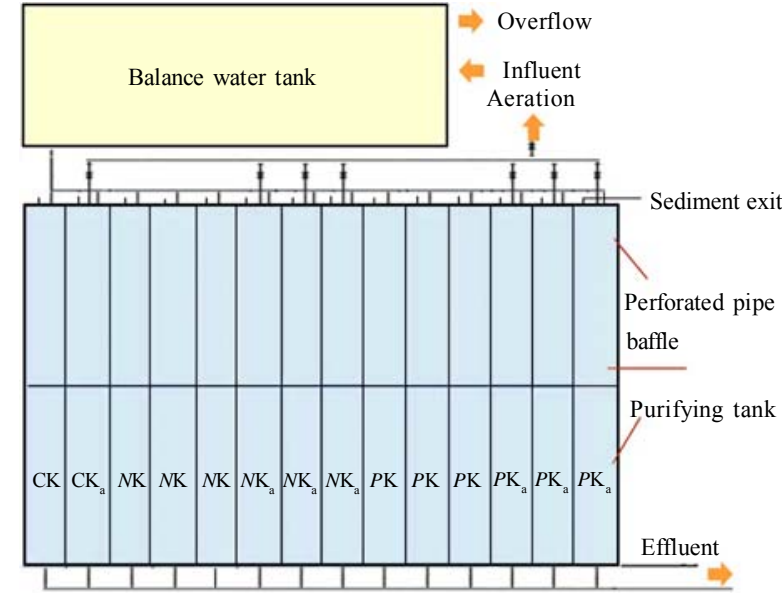

Fig. 3: Sketch of the plant purifying-tanks

with the same planting density of $13.0 / \mathrm{m}^{2}$ water area and two additional tanks without plant was as control. Treatment time was February -October 2008. Fig. 3 showed sketch of the purifying-tanks.

$P \mathrm{k}_{\mathrm{a}}$ and $P \mathrm{k}$ represented aeration and non aeration purifying-tank for $P$. cordata; $N \mathrm{k}_{\mathrm{a}}$ and $N \mathrm{k}$ represented aeration and non aeration purifying-tank for $N$. tetragona; $\mathrm{CK}_{\mathrm{a}}$ and $\mathrm{CK}$ represented aeration and non aeration control

\section{Sampling and analysis}

On October $2008,21^{\circ} \mathrm{C}-29^{\circ} \mathrm{C}$, sunny, seven plants (each plant had two or more leaf slices) were selected at random from the healthy plants in every purifyingtank and measured the roots (taproot) lengths, culms lengths and leaves (upper leaf) lengths were measured and measured standard deviations (SD) were calculated. Meanwhile, healthy leaves $(0.40 \mathrm{~g})$ and roots $(0.40 \mathrm{~g})$ were collected from each one of the selected plants for use. Corresponding water analysis of the effluent from each of 14 tanks was done using the standard methods (APHA, 1998).

\section{Chlorophyll content of the leaf of the aquatic plant}

Method reported by Hegedüs et al. (2001) was employed to analyze chlorophyll content and it was improved as follows: $0.05 \mathrm{~g}$ leaf was obtained and 5 $\mathrm{mL}$ of $80 \%$ acetone solution was added into, soaking $24 \mathrm{~h}$ and the absorbance of the soaked solution was measured with spectrophotometer (HITACHI U$1100)$. Its unit was $\mathrm{mg} / \mathrm{g}$. In this way, the chlorophyll content of the leaf of the aquatic plant was analyzed. 
Enzyme solution preparation

Fresh root $(0.30 \mathrm{~g})$ and leaf $(0.30 \mathrm{~g})$ were prepared and refined in the freezing phosphate solution $(\mathrm{pH}=$ 7.8), centrifuged at $13000 \mathrm{r} / \mathrm{min}$ and in $4^{\circ} \mathrm{C}$ for $30 \mathrm{~min}$. The supernatant was collected for the steps below.

\section{Soluble protein content and enzyme activities measure}

Soluble protein content of the leaf of the aquatic plant was measured with coomassie breiliant blue (Wessel and Flügge, 1984). Standard curve reported using bovine serum albumin and the unit was $\mathrm{mg} / \mathrm{g}$. Catalase activity measure of the root of the aquatic plant was determined with UV-spectromete (Rao et al. 1996; Aktar et al., 2009). D 240 value declined 0.1, represented one activity unit. Peroxidase activity measure of the root of the aquatic plant was performed with guaiacol (Zhang, 1990). Light intensity variation in per min represented the enzyme activity. D 460 value increased 0.1 , represented one activity unit and the unit was $\mathrm{U} /(\mathrm{g} \cdot \mathrm{min})$. In this way, the soluble protein content of the leaf of the aquatic plant and the catalase and peroxidase activity of the root of the aquatic plant were analyzed.

Nitrogen and phosphorus contents of the plant tissues and the biomass measure

Nitrogen contents in the samples of plant tissues including the roots, culms and leaves were determined by the Dumas combustion method using an automated CN analyser (LECOCHN-1000, LECO Company, St Joseph, MI, USA). Phosphorus contents in the corresponding plant tissues were determined by colourimetry (HITACHI U-1100 spectrophotometer) using the vanado-molybdate method after digesting material in a mixture of concentrated nitric and perchloric acids (Vogel and Bassett, 1978). The biomass (dry weight) of the plant tissues, including the roots and the shoots, was measured and the means of individual plant was obtained.

\section{Analytical methods}

Morphological and physiological indexes of seven plants of each purifying-tank were measured, and then the means of each index was obtained based on individual purifying-tank. And so did for the physical and chemical characteristics of the polluted water. In this way, three replicates (means) of each index were obtained and then the statistic analysis was conducted.
All data analysis was performed using independentsamples $t$ test of the SPSS 15.0 software.

\section{RESULTS AND DISCUSSION}

Effects of aeration on morphological characteristics of the aquatic plants

Under the conditions of long time continuous aeration, all the morphological characteristics of both plants were changed (Table 1).

Table 1 indicated that aeration affected morphological characteristics of the aquatic plants. Under the aeration conditions, the lengths of roots, culms and leaves decreased, respectively. Aeration was associated with the plants propagation. For $N$. tetragona, the tillers number in the non aeration tank was approximately 2.58 times of the aeration tank, due to the effects of water flow from the aeration on the roots growth. However, for $P$. cordata, the tillers in the aeration tank was about 1.60 times of the non aeration tank, because $P$. cordata under the non aeration conditions developed better than under the aeration conditions, sheltering the sunlight to be shared by the shootings, leading to the influence on the photosynthesis of the shootings and the growth of the tillers. However, the plants under the aeration conditions became comparatively dwarf, which was suitable for the shootings to catch sunlight and develop. Root density in the aeration tank was about 1.67 times of the non aeration tank, owing to the significant increase of the tillers.

Effects of aeration on physiological characteristics of the aquatic plants

Under the conditions of long period continuous aeration, all the physiological characteristics of both plants were changed (Table 2).

Table 2 indicated that aeration affected physiological characteristics of the aquatic plants. Under the aeration conditions, POD and CAT activities increased, respectively. Under two conditions, for $P$. cordata, CAT activities and the Chl (Chla, Chlb) contents varied significantly, while POD activities and SP contents did not. For $N$. tetragona, POD and CAT activities, SP, Chla and Chlb contents all varied significantly, respectively.

Aeration affected biomass and $\mathrm{N}$ and $\mathrm{P}$ contents of the plants tissues. Table 2 indicated that aeration influenced the biomass and the $\mathrm{N}$ and $\mathrm{P}$ contents of the plants tissues. In particular, the $\mathrm{N}$ and $\mathrm{P}$ contents 
Int. J. Environ. Sci. Tech., 7 (4), 665-674, Autumn 2010

Table1: Effects of aeration on the morphological characteristics of the aquatic plants

\begin{tabular}{|c|c|c|c|c|}
\hline Means & $\mathrm{N}-$ & $\mathrm{N}+$ & $\mathrm{P}-$ & $\mathrm{P}+$ \\
\hline Root length $(\mathrm{cm})$ & $42.36 \pm 4.13 \mathrm{a}$ & $21.39 \pm 2.46 \mathrm{~b}$ & $29.36 \pm 2.13 \mathrm{a}$ & $16.69 \pm 1.46 \mathrm{~b}$ \\
\hline Culm length (cm) & $35.27 \pm 3.51 \mathrm{a}$ & $30.97 \pm 2.40 \mathrm{~b}$ & $57.27 \pm 3.51 \mathrm{a}$ & $38.97 \pm 2.40 \mathrm{~b}$ \\
\hline Leaf length $(\mathrm{cm})$ & $7.67 \pm 0.83 \mathrm{a}$ & $4.34 \pm 0.51 \mathrm{~b}$ & $16.67 \pm 1.33 \mathrm{a}$ & $14.34 \pm 1.25 \mathrm{~b}$ \\
\hline Root density (roots $/ \mathrm{m}^{2}$ ) & $619 \pm 38.0 \mathrm{a}$ & $221 \pm 14.0 \mathrm{~b}$ & $1312 \pm 105 \mathrm{a}$ & $2194 \pm 167 b$ \\
\hline
\end{tabular}

Mean \pm S.D. $(\mathrm{n}=3)$, Means in the same line followed by the same letter $(\mathrm{a}, \mathrm{b})$ are not significantly different at $\mathrm{P}$-value $<0.05$ based on $t$ test. $N$ and $P$ were $N$. tetragona and P. cordata, + and - were aeration and non aeration conditions; the same table below.

Table: 2 Effects of aeration on the physiological characteristics of the aquatic plants

\begin{tabular}{|c|c|c|c|c|}
\hline Means & $\mathrm{N}-$ & $\mathrm{N}+$ & $\mathrm{P}-$ & $\mathrm{P}+$ \\
\hline POD activity $[\mathrm{U} /(\mathrm{g} \cdot \mathrm{min})]$ & $0.18 \pm 0.03 \mathrm{a}$ & $0.27 \pm 0.09 \mathrm{~b}$ & $0.07 \pm 0.020 \mathrm{a}$ & $0.10 \pm 0.03 \mathrm{a}$ \\
\hline CAT activity $[\mathrm{mg} /(\mathrm{g} \cdot \mathrm{min})]$ & $0.63 \pm 0.20 \mathrm{a}$ & $0.93 \pm 0.51 b$ & $0.54 \pm 0.090 \mathrm{a}$ & $0.72 \pm 0.16 b$ \\
\hline SP content (mg/g) & $41.58 \pm 9.75 \mathrm{a}$ & $32.93 \pm 5.69 \mathrm{~b}$ & $86.6 \pm 18.34 \mathrm{a}$ & $70.85 \pm 7.07 \mathrm{a}$ \\
\hline Chla content $(\mathrm{mg} / \mathrm{g})$ & $1.57 \pm 0.11 \mathrm{a}$ & $1.25 \pm 0.09 \mathrm{~b}$ & $1.85 \pm 0.070 \mathrm{a}$ & $1.53 \pm 0.19 b$ \\
\hline Chlb content (mg/g) & $0.49 \pm 0.02 \mathrm{a}$ & $0.37 \pm 0.02 \mathrm{~b}$ & $0.55 \pm 0.020 \mathrm{a}$ & $0.43 \pm 0.08 \mathrm{~b}$ \\
\hline \multicolumn{5}{|l|}{ Nitrogen content $(\mathrm{g} / \mathrm{kg})$ : } \\
\hline Root & $16.83 \pm 1.75 \mathrm{a}$ & $11.95 \pm 1.12 \mathrm{~b}$ & $17.91 \pm 1.820 \mathrm{a}$ & $12.87 \pm 1.23 \mathrm{~b}$ \\
\hline Culm & $23.12 \pm 1.97 \mathrm{a}$ & $16.25 \pm 1.35 \mathrm{~b}$ & $24.24 \pm 1.990 \mathrm{a}$ & $17.67 \pm 1.32 b$ \\
\hline Leaf & $26.13 \pm 2.01 \mathrm{a}$ & $18.51 \pm 1.52 \mathrm{~b}$ & $28.01 \pm 2.800 \mathrm{a}$ & $19.34 \pm 1.56 b$ \\
\hline \multicolumn{5}{|l|}{ Phosphorus content $(\mathrm{g} / \mathrm{kg})$} \\
\hline Root & $2.41 \pm 0.27 \mathrm{a}$ & $1.40 \pm 0.19 \mathrm{~b}$ & $2.45 \pm 0.290 \mathrm{a}$ & $1.42 \pm 0.20 \mathrm{~b}$ \\
\hline Culm & $3.18 \pm 0.27 \mathrm{a}$ & $1.92 \pm 0.16 b$ & $3.35 \pm 0.300 \mathrm{a}$ & $2.03 \pm 0.25 b$ \\
\hline Leaf & $3.57 \pm 0.31 \mathrm{a}$ & $2.18 \pm 0.26 \mathrm{~b}$ & $3.79 \pm 0.370 \mathrm{a}$ & $2.33 \pm 0.27 b$ \\
\hline \multicolumn{5}{|l|}{ Water content rate $(\%)$} \\
\hline Root & $92.5 \pm 1.60 \mathrm{a}$ & $94.0 \pm 2.20 \mathrm{a}$ & $91.2 \pm 1.70 \mathrm{a}$ & $93.4 \pm 2.20 \mathrm{a}$ \\
\hline Culm & $93.2 \pm 1.80 \mathrm{a}$ & $95.6 \pm 2.30 \mathrm{a}$ & $92.3 \pm 1.80 \mathrm{a}$ & $94.5 \pm 2.30 \mathrm{a}$ \\
\hline Leaf & $93.6 \pm 1.90 \mathrm{a}$ & $96.5 \pm 2.40 \mathrm{a}$ & $92.9 \pm 2.10 \mathrm{a}$ & $95.1 \pm 2.50 \mathrm{a}$ \\
\hline \multicolumn{5}{|l|}{ Biomass (g/plant) } \\
\hline Root & $23.67 \pm 1.05 \mathrm{a}$ & $19.66 \pm 0.74 b$ & $20.55 \pm 0.67 \mathrm{a}$ & $17.06 \pm 0.61 \mathrm{a}$ \\
\hline Shoot & $2.92 \pm 0.10 \mathrm{a}$ & $2.47 \pm 0.08 \mathrm{~b}$ & $9.39 \pm 0.34 \mathrm{a}$ & $7.94 \pm 0.30 \mathrm{~b}$ \\
\hline
\end{tabular}

Mean \pm S.D. $(\mathrm{n}=3)$, Means in the same line followed by the same letter $(\mathrm{a}, \mathrm{b})$ are not significantly different at P-value $<0.05$ based on $t$ test. $N$ and $P$ were $N$. tetragona and P. cordata, + and - were aeration and non aeration conditions

of the roots, culms and leaves decreased under the aeration conditions, respectively. It was because aeration affected the roots development, leading to the decrease of the $\mathrm{N}$ and $\mathrm{P}$ absorption of the roots, which directed to the decrease of the $\mathrm{N}$ and $\mathrm{P}$ accumulation of the culms and leaves tissues. Furthermore, under the non aeration conditions, the plants developed better, biomass of per plant was larger and the water content ratios of the plants tissues under two conditions did not vary significantly (Table 2), which indicated that the $\mathrm{N}$ and $\mathrm{P}$ absorption of per plant under the aeration conditions was weaker than under the non aeration conditions.

Aeration possibly affected the photosynthesis and transpiration of the aquatic plants. Chla and Chlb contents of the leaves of two plants under the aeration conditions were lower than under the non aeration conditions (Table 2), because the continuous water flow caused by the continuous pressurized (convective) gas flow from the aerator, influencing the development of the exposed roots. Thus, the physiological status of the plants was affected, leading to the decline of the synthesis ability of the photosynthetic pigments of the leaves. However, Chl (Chla, Chlb) contents were obviously associated with the effective photosynthesis rates of the leaves. Therefore, aeration influenced the plants photosynthesis and the SP production.

Aeration possibly affected the transpiration of the plants. $\mathrm{N}$ and $\mathrm{P}$ contents of per unit of mass of the plant tissues including the root, culm and leaf under the aeration conditions were lower than under the non aeration conditions, the corresponding water content ratios did not vary significantly (Table 2 ) and the plants developed better under the non aeration conditions (Table 1), all that indicated that the soluble $\mathrm{N}$ and $\mathrm{P}$ absorption of the plants from the water in the aeration tank was weaker than in the non aeration tank in the same treatment period. Therefore, the transpiration absorption of the plants under the aeration conditions 
was weaker than under the non aeration conditions. $\mathrm{N}$ and $\mathrm{P}$ were essential nutrients for the plants growth, thus, aeration affected the plants growth (Table 1).

Aeration also affected anti-enzyme activities of the plants. Enzyme activity was associated with the physiologic status of the plants. Adversity resulted in the super oxide radicals increased in the plant cells (Jabs, 1999). CAT and POD had synergy effect in scavenging and preventing the active oxygen radicals (Kaufmann et al. 2002; Martí et al. 2009). POD responded sensitively to the adverse conditions (Tan et al. 2006) and it was obviously associated with the plant resistance (Li et al. 2000).

Aquatic plant growth was usually determined by water quality, sediment mud quality and hydrological conditions. In this study, because it was a water culture experiment, there was no effect of the sediment mud on the plants growth. Continuous pressurized (convective) gas flow from the aerator changed the microcosmic hydrological conditions of the tanks. The pressurized (convective) gas flow most likely injured some exposed roots, especially the tender ones, affecting the plants growth. And the plants responded physiologically, such as the decline of Chla, Chlb and SP contents and the increase of POD and CAT activities (Table 2). The mechanism of this phenomenon was different to the reports of Li et al. (2007). They reported that while the aquatic plant was soaked in heavily polluted water for a long period, the POD activity of the plant roots increased, due to the absorption for numerous soluble pollutants from the water. Recently, other reports indicated (Liszkayet al. 2003; Hou et al. 2004) that POD played an important role healing the injury for the plant, distributing extensively in the callus and it was associated with the plant cell growth and the plant structure regeneration.

\section{Effects of aeration on the polluted water qualities}

Long period continuous aeration influenced the $\mathrm{COD}_{\text {cr }}, \mathrm{N}$ and $\mathrm{P}$ removal rates of the polluted river water (Table 3).

Table 3 indicated that aeration affected the water purification. For the tank with $P$. cordata, DO concentrations, $\mathrm{COD}_{\mathrm{cr}}, \mathrm{TN}$ and $\mathrm{NH}_{4}^{+}-\mathrm{N}$ removals under the aeration conditions increased, respectively. While the removal ratios of TP and soluble $\mathrm{P}$ under two conditions did not vary significantly. For the tank with $N$. tetragona, DO increased $1.57 \mathrm{mg} / \mathrm{L}$ under the aeration conditions, while $\mathrm{COD}_{\mathrm{cr}}, \mathrm{TN}, \mathrm{NH}_{4}^{+}{ }^{+} \mathrm{N}, \mathrm{TP}$ and soluble $\mathrm{P}$ removal ratios decreased under the non aeration conditions. Aquatic plants were dependent on transpiration to absorb and remove the soluble $\mathrm{N}$ and P of polluted water (Luo et al. 2006; Suthar and Singh, 2008). The decrease of soluble $P$ removal under the aeration conditions was because the soluble $\mathrm{P}$ sedimentation and the plant transpiration were influenced by the aeration. In the aeration tank with $P$. cordata, higher DO concentration was suitable for heterotrophic microbes to remove $\mathrm{COD}_{\mathrm{cr}}$. Lower $\mathrm{pH}$ value in the aeration tank was resulted from the higher $\mathrm{NH}_{4}^{+}-\mathrm{N}$ removal. For the tank with $N$. tetragona, the $\mathrm{pH}$ value decrease under the non aeration conditions was due to the higher $\mathrm{NH}_{4}^{+}-\mathrm{N}$ removal. $\mathrm{COD}$ cr removal increase under the non aeration conditions was due to the obviously larger area of the roots surface, leading to more heterotrophic microbes of the biofilm on the roots developed, causing the better degradation and decomposition of the organic pollutants. Additionally, good sedimentation in the non aeration tank also played a role in removing $\mathrm{COD}_{\mathrm{cr}}$.

\section{Effects of aeration on the $N$ removal of the polluted water}

Aeration affected $\mathrm{N}$ removal of the polluted water by the aquatic plants. $\mathrm{NH}_{4}^{+}-\mathrm{N}$ of polluted water was the important source for the $\mathrm{N}$ require of the aquatic plant tissues (Fan and Li, 2005). Friday and Quarmby (1994) reported that when $\mathrm{NH}_{4}^{+}-\mathrm{N}$ existed along with $\mathrm{NO}_{3}{ }^{-} \mathrm{N}, \mathrm{NH}_{4}{ }^{+}-\mathrm{N}$ had advantage to be absorbed by the aquatic plants. The most important factor influencing $\mathrm{N}$ absorption was the root surface area, inner structure and water quality (Fan and Li, 2005). In this study, for $N$. tetragona, effects of aeration on the plant transpiration played a role in removing N. Most importantly, in the aeration tank, the shorter and the lower density of the plant roots resulted in the decline of microbes of the biofilm on the roots. Therefore, although there was higher DO in the aeration tank, the N removals between two types tanks did not vary significantly. In particular, although DO concentration in the aeration tank was about 2.73 times of the non aeration tank (Table 3), being suitable for aerobic microbes to degrade and decompose $\mathrm{NH}_{4}^{+}$-N (Bodelier et al.1996; Kowalchuk et al.1998; Kirk and Kronzucker, 2005; Scholz and Lee, 2005; Ouellet-Plamondon et al. 2006), aeration significantly affected the growth of the plants, leading to the obvious decline of the root length and the root density. The root length and the root density in the non aeration tank were about 1.98 times and 2.80 times 
Int. J. Environ. Sci. Tech., 7 (4), 665-674, Autumn 2010

Table 3: Effects of aeration on the water purification by the aquatic plants

\begin{tabular}{lrrrr}
\hline Means & \multicolumn{1}{c}{$\mathrm{N}-$} & $\mathrm{N}+$ & $\mathrm{P}-$ & $\mathrm{P}+$ \\
\hline TP removal rate $(\%)$ & $30.43 \pm 2.01 \mathrm{a}$ & $22.01 \pm 0.890 \mathrm{~b}$ & $34.35 \pm 2.37 \mathrm{a}$ & $30.69 \pm 2.11 \mathrm{a}$ \\
Soluble P removal rate (\%) & $30.00 \pm 2.16 \mathrm{a}$ & $21.95 \pm 0.840 \mathrm{~b}$ & $37.50 \pm 2.18 \mathrm{a}$ & $34.31 \pm 2.02 \mathrm{a}$ \\
TN removal rate $(\%)$ & $27.08 \pm 1.65 \mathrm{a}$ & $23.51 \pm 1.170 \mathrm{a}$ & $30.69 \pm 1.49 \mathrm{a}$ & $45.13 \pm 2.01 \mathrm{~b}$ \\
$\mathrm{NH}_{4}^{+}-\mathrm{N}$ removal rate $(\%)$ & $29.63 \pm 1.56 \mathrm{a}$ & $25.35 \pm 1.590 \mathrm{a}$ & $33.28 \pm 2.09 \mathrm{a}$ & $49.34 \pm 3.07 \mathrm{~b}$ \\
$\mathrm{COD}_{\text {cr removal rate }(\%)}$ & $43.62 \pm 2.83 \mathrm{a}$ & $39.57 \pm 2.370 \mathrm{a}$ & $48.32 \pm 2.74 \mathrm{a}$ & $60.65 \pm 3.31 \mathrm{~b}$ \\
DO concentration $(\mathrm{mg} / \mathrm{L})$ & $0.91 \pm 0.04 \mathrm{a}$ & $2.48 \pm 0.120 \mathrm{~b}$ & $0.98 \pm 0.05 \mathrm{a}$ & $2.56 \pm 0.13 \mathrm{~b}$ \\
pH value & $8.2 \pm 0.10 \mathrm{a}$ & $8.3 \pm 0.100 \mathrm{a}$ & $8.1 \pm 0.10 \mathrm{a}$ & $7.7 \pm 0.10 \mathrm{~b}$ \\
Water temperature $\left({ }^{\circ} \mathrm{C}\right)$ & $26.1 \pm 0.10 \mathrm{a}$ & $25.3 \pm 0.100 \mathrm{a}$ & $26.0 \pm 0.10 \mathrm{a}$ & $25.1 \pm 0.10 \mathrm{a}$ \\
\hline
\end{tabular}

Mean \pm S.D. $(\mathrm{n}=3)$, Means in the same line followed by the same letter $(\mathrm{a}, \mathrm{b})$ are not significantly different at P-value $<0.05$ based on $t$ test. $N$ and $P$ were $N$. tetragona and P. cordata, + and - were aeration and non aeration conditions

of the aeration tank (Table 1), leading to the significant variation between the root surface areas of two tanks, which most possibly made the microbes of the biofilm on the roots vary significantly. In addition, aeration affected the $\mathrm{N}$ absorption of the plant roots.

For the tank with $P$. cordata, although $\mathrm{N}$ absorption of per plant declined under the aeration conditions, $\mathrm{TN}$ and $\mathrm{NH}_{4}^{+}-\mathrm{N}$ removals were obviously higher than under the non aeration conditions (Table 3 ), since the DO increased significantly in the aeration tank, which was suitable for anoxic and aerobic microbes (e. g. nitrite bacteria and nitrifying bacteria) of the biofilm on the roots to decompose $\mathrm{NH}_{4}^{+}-\mathrm{N}$ (Bodelier et al., 1996; Kowalchuk et al., 1998; Kirk and Kronzucker, 2005). Luo et al. (2006) reported that $\mathrm{N}$ absorption of the aquatic plant was only approximately $17 \%$ of the $\mathrm{N}$ removal of the polluted water, and the most $\mathrm{N}$ removal was critically performed by microbes (Bodelier et al.1996; Kowalchuk et al.1998; Kirk and Kronzucker, 2005). In particular, the root in the non aeration tank was longer than in the aeration tank, approximately 1.76 times (Table 1), while the root density of the aeration tank was approximately 1.67 times of the non aeration tank (Table 1). Thus, for P. cordata, the surface areas of the roots between two tanks most possibly did not vary significantly. However, DO in the aeration tank was approximately 2.61 times of the non aeration tank (Table 3), which was more suitable for aerobic microbes to degrade and decompose $\mathrm{NH}_{4}^{+}$N (Bodelier et al., 1996; Kowalchuk et al., 1998; Kirk and Kronzucker, 2005), leading to the obvious increase of the $\mathrm{N}$ removal.

Effects of aeration on the P removal of the polluted water

$P$ removal of the polluted water was affected by the aeration. Soluble P absorption by the roots from polluted water was determined by the biological character of the root and the water quality (Fan and Li,
2005). After soluble $P$ was absorbed by the roots from water (Thiebaut and Muller, 2003), it was then transported to the shoots (Baldy et al., 2007). For $N$. tetragona, tiller, biomass, root length, root density and the $\mathrm{P}$ content of the plant all obviously decreased under the aeration conditions (Tables 1 and 2). Compared to the non aeration conditions, the removal of TP and soluble $\mathrm{P}$ of the polluted water by the plant obviously decreased $8.42 \%$ and $8.05 \%$ (Table 3 ) under the aeration conditions. However, for the tank with $P$. cordata, P removals of the polluted water under two conditions did not vary significantly (Table 3). It was because although biomass, root length and the $\mathrm{P}$ content of per plant decreased, tillers and root density increased obviously under the aeration conditions.

In general, effects of aeration on the TN and TP removals of the water by $N$. tetragona were more significant than by $P$. cordata. Under the aeration conditions, TN and TP removals of the water by N. tetragona were $23.51 \%$ and $22.01 \%$ and they turned to $45.13 \%$ and $30.69 \%$ by $P$. cordata, respectively. Therefore, the TN and TP removals of the water by $P$. cordata were better than by $N$. tetragona under the aeration conditions.

Effects of the aeration on the morphological and physiological characteristics of $N$. tetragona and the water purification by the plant were more significant than P. cordata. In particular, aeration did not affect the POD activity and the SP content significantly for $P$. cordata, whereas they varied significantly for $N$. tetragona. Aeration contributed to the obvious decline of both the tillers and the roots density of $N$. tetragona, while they changed contrarily for $P$. cordata. Therefore, $P$. cordata comparatively developed better than $N$. tetragona under the same aeration conditions. Aeration resulted in the decline of $\mathrm{COD}_{\mathrm{cr}}, \mathrm{TN}$ and $\mathrm{NH}_{4}^{+}-\mathrm{N}$ removals and a somewhat 
increase of $\mathrm{pH}$ value in the tank with $N$. tetragona, while $\mathrm{COD}_{\mathrm{cr}}, \mathrm{TN}$ and $\mathrm{NH}_{4}^{+}-\mathrm{N}$ removals in the aeration tank with $P$. cordata were higher than in the non aeration tank and directed to a somewhat decrease of the $\mathrm{pH}$ value in the aeration tank. Furthermore, TN and TP removals of the water by $P$. cordata were higher than by $N$. tetragona under the aeration conditions. Therefore, in the ecological restoration engineering of stagnant water, when different aquatic plants (such as $P$. cordata with good growth and water purification ability, $N$. tetragona with good ornamental value and less prominent ability of the water purification and poor develop character) were prepared to plant on the floating-beds, the layout of the planted sites and the aerators sites should be optimized carefully. Only in this way, effective water purification was able to be achieved and maintained continuously, along with the environment beautification.

Same analysis was performed on the other two days April $26^{\text {th. }} 2008$ and July $19^{\text {th. }} 2008$ and the similar results were obtained (data omitted). The results indicated that effects of aeration on the aquatic plants and the water purification were more significant on October $11^{\text {st. }} 2008$ than on the other two days under the similar growth conditions as the former day for the plants, which was possibly due to the difference of the plants' physiological status at their different growth stages.

Finally, it can be concluded, both $N$. tetragona and $P$. cordata developed well and had good removals of $\mathrm{N}$ and $\mathrm{P}$ in heavily polluted stagnant water. While long period continuous aeration affected the physiological status of the aquatic plants and the $\mathrm{N}$ and $\mathrm{P}$ removals of the polluted water. The effects became more significant on $N$. tetragona than $P$. cordata. Change in the physiological response of the aquatic plants for the aeration generally corresponded to the variation of $\mathrm{N}$ and P removals of the polluted water.

Aeration contributed to the increase of POD and CAT activities of two plants and the decrease of SP, Chla, Chlb, $\mathrm{N}$ and $\mathrm{P}$ contents and biomass of the plants. Aeration resulted in the tillers and the roots densities of $N$. tetragona decreased, while they changed contrarily for $P$. cordata.

Under the aeration conditions, for the tank with $N$. tetragona, TP and soluble $\mathrm{P}$ removals of polluted water obviously decreased, and for the tank with $P$. cordata, TN and $\mathrm{NH}_{4}^{+}-\mathrm{N}$ removals of polluted water obviously increased. The TP and soluble P removals for the tank with $P$. cordata and the TN and
$\mathrm{NH}_{4}^{+}-\mathrm{N}$ removals for the tank with $N$. tetragona, did not vary significantly under two conditions, respectively. $P$. cordata was more suitable to develop and remove TN and TP of the polluted water than $N$. tetragona under the aeration conditions, and the removal rates reached $45.13 \%$ and $30.69 \%$, respectively.

In conclusion, the effects of artificial aeration on the physiological characteristics of the aquatic plants were heavier at the final growth stages of the plants than at the other growth stages. Particularly, they were more significant on $N$. tetragona than on P. cordata. However, the change tendency of the water qualities differed to the variation of the physiological characteristics of the plants.

\section{ACKNOWLEDGMENTS}

The authors would like to thank the School of Resource and Environment Sciences of East China Normal University for extending their cooperation and assistance for conducting this study by providing facilities. The work was funded by the National Scientific and Technological Major Program of China with the grand number of 2008ZX07317-006.

\section{REFERENCES}

Akpor, O. B.; Momba, M. N. B.; Okonkwo, J. O.; Coetzee, M. A., (2008). Nutrient removal from activated sludge mixed liquor by wastewater protozoa in a laboratory scale batch reactor. Int. J. Environ. Sci. Tech., 5 (4), 463-470 (9 pages).

Aktar, W.; Paramasivam, M.; Sengupta, D., (2009). Persistence of benthiocarb in soil: Influence of ultraviolet and sunlight. Int. J. Environ. Res., 3 (3), 349-352 (4 pages).

APHA, (1998). Standard methods for the examination of Water and wastewater. 20 $0^{\text {th. }}$ Ed. American Public Health Association, American Water Works Association, Water Environment Federation, Washington DC, USA.

Baldy, V.; Trémolières, M.; Andrieu, M.; Belliard, J., (2007). Changes in phosphorus content of two aquatic macrophytes according to water velocity, trophic status and time period in hardwater streams. Hydrobiologia, 575 (1), 343-351 (9 pages).

Banu, R. J.; Do, K. U.; Yeom, I. T., (2008). A study on phosphorus removal in low alkalinity secondary effluent using alum. Int. J. Environ. Sci. Tech., 5 (1), 93-98 (6 pages).

Bodelier, P. L. E.; Libochant, J. A.; Blom, C. W. P. M.; Laanbroek, H. J., (1996). Dynamics of nitrification and denitrification in root-oxygenated sediments and adaptation of ammonia-oxidizing bacteria to low-oxygen or anoxic habitats. Appl. Environ. Microbiol., 62 (11), 4100-4107 (8 pages).

Davies, L. C.; Carias, C. C.; Novais, J. M.; Martins-Dias, S., (2005). Phytoremediation of textile effluents containing azo dye by using Phragmites australis in a vertical flow 
intermittent feeding constructed wetland. Ecol. Eng., 25 (5), 594-605 (12 pages).

Dhote, S.; Dixit, S., (2009). Water quality improvement through macrophytes-a review. Environ. Monit. Assess., 152 (1-4), 149-153 (5 pages).

El-Diwani, G.; El Rafie, S.; Hawash, S., (2009). Degradation of 2, 4, 6-trinitotoluene in aqueous solution by ozonation and multi-stage ozonation-biological treatment. Int. J. Environ. Sci. Tech., 6 (4), 619-628 (10 pages).

Fan, G. L.; Li, W., (2005). Response of nutrient accumulation characteristics and nutrient strategy of Myriophyllum spicatum L. under different eutrophication conditions. J. Wuhan Bot. Res., 23 (3), 267-271 (5 pages).

Friday, L.; Quarmby, C., (1994). Uptake and translocation of prey-derived ${ }^{15} \mathrm{~N}$ and ${ }^{32} \mathrm{P}$ in Utricularia vulgaris L. New Phytol., 126 (2), 273-281 (9 pages).

Guo, X.; Kim, J. H.; Behera, S. K.; Park, H. S., (2008). Influence of dissolved oxygen concentration and aeration time on nitrite accumulation in partial nitrification process. Int. J. Environ. Sci. Tech., 5 (4), $527-534$ (8 pages).

Hegedüs, A.; Erdei, S.; Horváth, G., (2001). Comparative studies of $\mathrm{H}_{2} \mathrm{O}_{2}$ detoxifying enzymes in green and greening barley seedlings under cadmium stress. Plant Sci., 160 (6), 1085-1093 (9 pages).

Hou, H. W.; Kalima-N'Koma, M.; Wang, Y. Q.; Cui, K. M., (2004). Changes of soluble protein, peroxidase activity and distribution during regeneration after girdling in Eucommia ulmoides. Acta Botanica Sinica, 46 (2), $216-$ 223 (8 pages).

Igbinosa, E. O.; Okoh, A. I., (2009). Impact of discharge wastewater effluents on the physico-chemical qualities of a receiving watershed in a typical rural community. Int. J. Environ. Sci. Tech., 6 (2), 175-182 (8 pages).

Jabs, T., (1999). Reactive oxygen intermediates as mediators of programmed cell death in plants and animals. Biochem. Pharmacol., 57 (3), 231-245 (15 pages).

Judith, S. W.; Peddrick, W., (2004). Metal uptake, transport and release by wetland plants: implications for phytoremediation and restoration. Environ. Int., 30 (5), 685-700 (16 pages).

Kaufmann, J. A.; Bickford, P. C.; Taglialatela, G., (2002). Free radical-dependent changes in constitutive nuclear factor kappa B in the aged hippocampus. Neuroreport, 13 (15), 1917-1920 (4 pages).

Kirk, G. J. D.; Kronzucker, H. J., (2005). The potential for nitrification and nitrate uptake in the rhizosphere of wetland plants: a modelling study. Ann. Bot., 96 (4), 639646 (8 pages).

Kovacic, D. A.; Twait, R. M.; Wallace, M. P.; Bowling, J. M., (2006). Use of created wetlands to improve water quality in the Midwest-Lake Bloomington case study. Ecol. Eng., 28 (3), 258-270 (13 pages).

Kowalchuk, G. A.; Bodelier, P. L. E.; Heilig, G. H. J.; Stephen, J. R.; Laanbroek, H. J., (1998). Community analysis of ammonia-oxidising bacteria, in relation to oxygen availability in soils and root-oxygenated sediments, using PCR, DGGE and oligonucleotide probe hybridization. FEMS Microbiol. Ecol., 27 (4), 339-350 (12 pages).

Li, J.; Yan, X. F.; Zu, Y. G., (2000). Generation of activated oxygen and change of cell defense enzyme activity in leaves of Korean pine seedling under low temperature.
Acta Botanica Sinica, 42 (2), 148-152 (5 pages).

Liszkay, A.; Kenk, B.; Schopfer, P., (2003). Evidence for the involvement of cell wall peroxidase in the generation of hydroxyl radicals mediating extension growth. Planta, 217 (4), 658-667 (10 pages).

Li, Z. H.; Tang, W. H.; Song, Z. W., (2007). Response of the morphological and physiological characteristics of aquatic plants to long-term soaking in the process of constructed wetland wastewater treatment. Acta Scientiae Circumstantiae, 27 (1), 75-79 (5 pages).

Luo, W. G.; Wang, S. H.; Huang, J.; Yan, L.; Huang, J.,(2006). Influence of plant photosynthesis and transpiration character on nitrogen removal effect in wetland. China Environ. Sci., 26 (1), 30-33 (4 pages).

Madukasi, E. I.; Dai, X.; He, C.; Zhou, J., (2010). Potentials of phototrophic bacteria in treating pharmaceutical wastewater. Int. J. Environ. Sci. Tech., 7 (1), 165-174 (10 pages).

Martí, M. C.; Camejo, D.; Fernández-García, N.; RellánÁlvarez, R.; Marques, S.; Sevilla, F.; Jiménez, A., (2009). Effect of oil refinery sludges on the growth and antioxidant system of alfalfa plants. J. Hazard. Mater., 171 (1), 879885 (7 pages).

Nahlik, A. M.; Mitsch, W. J., (2006). Tropical treatment wetlands dominated by free-floating macrophytes for water quality improvement in Costa Rica. Ecol. Eng., 28 (3), 246-257 (12 pages).

Ouellet-Plamondon, C.; Chazarenc, F.; Comeau, Y.; Brisson, J., (2006). Artificial aeration to increase pollutant removal efficiency of constructed wetlands in cold climate. Ecol. Eng., 27 (3), 258-264 (7 pages).

Rao, M. V.; Paliyath, G.; Ormrod, D. P., (1996). Ultraviolet$\mathrm{B}$ and ozone-induced biochemical changes in antioxidant enzymes of Arabidopsis thaliana. Plant Physiol., 110 (1), 125-136 (12 pages).

Scholz, M.; Lee, B. H., (2005). Constructed wetlands: a review. Int. J. Environ. Stud., 62 (4), $421-447$ (27 pages).

Soltanali, S.; Shams Hagani, Z., (2008). Modeling of air stripping from volatile organic compounds in biological treatment processes. Int. J. Environ. Sci. Tech., 5 (3), 353-360 (8 pages)

Subhasis, G.; Walter, J. W.; Jr.; Alisa, M. R.; James, E. T.; Brad, L. U., (1999). Epigenetic toxicity of a mixture of polycyclic aromatic hydrocarbons on gap junctional intercellular communication before and after biodegradation. Environ. Sci. Tech., 33 (7), 1044-1050 (7 pages).

Suthar, S.; Singh, S., (2008). Vermicomposting of domestic waste by using two epigeic earthworms (Perionyx excavatus and Perionyx sansibaricus). Int. J. Environ. Sci. Tech., 5 (1), 99-106 (8 pages).

Tan, Y.; Liang, Z. S.; Shao, H. B.; Du, F., (2006). Effect of water deficits on the activity of anti-oxidative enzymes and osmoregulation among three different genotypes of Radix Astragali at seeding stage. Colloids Surf. B: Biointerfaces, 49 (1), 60-65 (6 pages).

Thakre, S. B.; Bhuyar, L. B.; Deshmukh, S. J., (2009). Oxidation ditch process using curved blade rotor as aerator. Int. J. Environ. Sci. Tech., 6 (1), 113-122 (10 pages).

Thiebaut, G.; Muller, S., (2003). Linking phosphorus pools 
of water, sediment and macrophytes in running waters. Ann. Limnologie-Int. J. Limnology, 39 (4), 307-316 (10 pages).

Vogel, A. I.; Bassett, J., (1978). Vogel's textbook of quantitative inorganic analysis, including elementary instrumental analysis $4^{\text {th. }}$ Edn. London and New York.

Wessel, D.; Flügge, U. I., (1984). A method for the quantitative recovery of protein in dilute solution in the presence of detergents and lipids. Anal. Biochem., 138 (1), 141-143 (3 pages).

Yousaf, A.; Sarwar, G., (2008). Genotypic X environmental interaction of Cowpea genotypes. Int. J. Environ. Res., 2 (2), 125-132 (8 pages).

Zhang, Z. L., (1990). Laboratory Precedure of Plant Physiology. Beijing, China: Higher Educational Press.

\section{AUTHOR (S) BIOSKETCHES}

Lu, X. M., Ph.D., Research ecologist, Institute for Eco-environmental Sciences, Wenzhou Vocational College of Science and Technology,

Zhejiang, China. Email: xm155@sina.com

Huang, M. S., Ph.D., Research ecologist, School of Resources and Environment Sciences, East China Normal University, Shanghai, China. Email: cxh155@sina.com

How to cite this article: (Harvard style)
Lu, X. M.; Huang, M. S., (2010). Nitrogen and phosphorus removal and physiological response in aquatic plants under aeration conditions.
Int. J. Environ. Sci. Tech., 7 (4), 665-674.

